\title{
Visual Impact of Tectonic Movements on the Caves in Andaman Islands
}

Study Area: Andaman \& Nicobar islands, India

Coordinates: $6^{\circ} 45^{\prime} \& 13^{\circ} 41^{\prime} \mathrm{N}$ latitudes and $92^{\circ} 12^{\prime} \& 93^{\circ} 57^{\prime} \mathrm{E}$ longitudes

Key words: Submerged Caves, Land upliftment, Cave swiftlet, Tsunami

\section{Introduction:}

Caves are considered as unique natural laboratories for studying biological and geological processes. Constant geophysical characteristics, perpetual darkness, low energy input with all such unique characteristics caves harbour a typical set of fauna especially adapted for the subterranean environments (Biswas, 2010; Biswas \& Harries, 2011). The region of the Burmese arc including the Andaman and Nicobar Islands is characterized by highly seismic, seismic and aseismic zones, with earthquake segments of shallow to intermediate centre in the earth crust (Kumar, 1990). The tectonic activity of the Andaman area is intense along two broad belts: the western non-volcanic arc comprising the Andaman Nicobar Islands, and the eastern volcanic arc. The eastern island arc is the most active belt along which a lithospheric convergence has taken place (Jafri et al., 1993).

A subduction of the Indo-Burma plate occurred due to the M 9.15 earthquake in 26 December 2004, the epicentre of which was located $150 \mathrm{~km}$ off the west coast of northern Sumatra Island in Indonesia (Sankaran et al., 2005). It led to significant ground deformation in the Andaman and Nicobar region. As the Andaman and Nicobar Islands lie within the subduction zone of the Burma plate, north of the epicentre of mega tsunami, it was the most affected region in India (Rao \& Chary, 2005; Jain et al., 2005; Sankaran et al., 2005; Rajendran et al., 2007). In the subsequent months, series of aftershocks were also realized. The Mega-disaster not only affected people but also the ecosystems and wildlife (Sankaran et al., 2005) in these islands. As per Manchi \& Sankaran (2009) cave habitats of these islands werealso affected severely due to this geological disaster.

Though, the earlier report of Manchi \& Sankaran (2009) was restricted to the inland caves at Chalis-ek on North Andaman and caves on interview Islands, further more of a special survey was done where all types of caves were considered on the basis of visual qualitative impacts rather than quantifying it. In the present survey, our major focus was to know the effect of the tectonic activity on different types of caves.

Area Surveyed:

Sankaran (1998) located and mapped 384 caves in Andaman and Nicobar islands, of which 236 (61.5\%) were inland caves (located in forests) and the rest were coastal caves (located on the shore). Among the 236 inland caves, $86 \%$ were underground out of which $1 \%$ was located at the origin of a stream. Fourteen percent of the caves apparent above the ground were sub-divided as located above ground on

*Author: ediblenest@gmail.com 
inland cliffs (3\%) and 97\% on inland hills (Sankaran, 1998; 2001).

In the present survey total 314 caves in North plus Middle Andaman and Ritchi's Archipelago were visited. The survey was done during February and March months of 2012 \& 13. All the explored caves were observed minutely and the post-tsunami changes like rock fall inside the cave and/or opening/closing of the cave entrances etc. were documented minutely. For understanding the changes in the type of caves we followed the standards described by Sankaran (1998) and all the 384 limestone caves known from the Andaman \& Nicobar islands were categorized as per Sankaran (1998) into eight particular types (Table 1).

\section{Observations and Discussion :}

Out of 384 limestone caves, 325 caves in Andaman islands were of five types. The number of Post tsunami type of caves in Andaman islands did not change but Kruskal-Wallis $\mathrm{H}$ test showed the types did differ considerably $(\div 2=16.040, \mathrm{p}=0.042$; Table 1$)$. The coastal caves seem to be affected signif icantly, showing major alterations in the types of caves preand post tsunami.

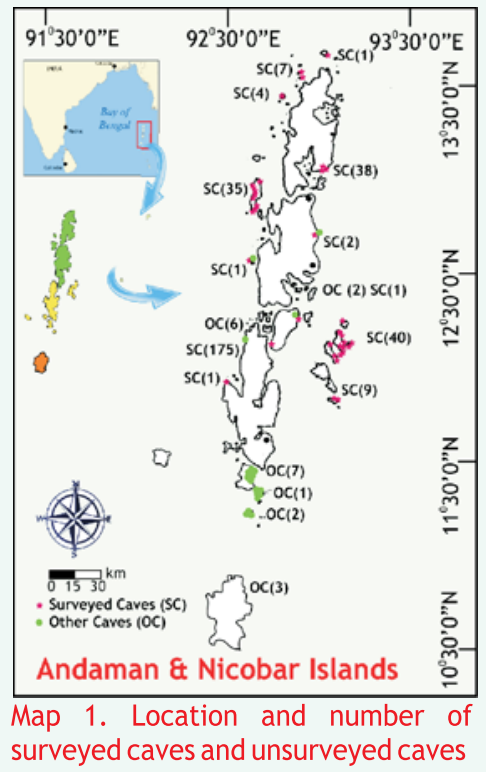

Table 1. Cave types in the Andaman Islands pre (Sankaran, 1998) and post (Manchi, 2014) tsunami disaster

\begin{tabular}{lllllllllr}
\hline Cave Type* & A & AB & B & BD & Ci & Cii & Ciii & D & Total \\
\hline Pre-tsunami (Sankaran, 1998) & o & 1 & 92 & 3 & 0 & 199 & 0 & 30 & 325 \\
Post-tsunami (Present Report) & 2 & 14 & 72 & 3 & 0 & 199 & 0 & 30 & 320 \\
Differencein number of caves & +2 & +13 & -20 & 0 & 0 & 0 & 0 & 0 & 15 \\
Caves closed & & & 5 & & & & & & 5 \\
New caves found (Present Report) & 1 & & 2 & & & 7 & & & 10 \\
\hline
\end{tabular}

*Table Legends: $A=$ On, coast approachable on foot; B = On, coast, entrance partially submerged and access by swimming into cave; $\mathrm{AB}=\mathrm{On}$ coast, Approachable on foot after swimming ashore; $\mathrm{BD}=$ Cave above sea level on cliff face ending in the sea; $\mathrm{Ci}$ = In the forest, at the origin of stream; $\mathrm{Cii}=\mathrm{In}$ the forest, cavern bellow the ground; $\mathrm{Ciii}=\mathrm{In}$ the forest; D = Midway on inland cliff; E = Japanese bunker (manmade tunnel). (+) indicates addition and (-) indicates decline in cave number.

Of the four types of coastal caves (Table 1), type B were found to be the most affected (Manchi \& Sankaran, 2009). In the present survey, other than the caves reported earlier few other caves were also found to be affected by the dislocation of huge rocks inside. Entrances of Five caves ( 2 caves on Henry Lowrence and 3 caves on South Button Islands) are permanently closed because of the heavy rock fall at cave opening. Dislocated rock blocked the cave entrances leaving small spaces which may allow aeration and insect trafficking from the cave.

Since caves are the biosphere having a complete isolated ecosystem, it becomes very important to understand each biotic and abiotic systems of it in detail. The caves once collapsed perhaps get buried with itself all such precious species which were either unknown to the world or endemic to that particular cave (Biswas, 2009). Nevertheless, the rack fall rising of land out of the sea by almost $1.32 \mathrm{M}$ (Sankaran et al., 2005) converted 15 submerged coastal caves (B type) into dry caves i.e. A (2 caves) and $\mathrm{AB}$ (13 caves). It is quite obvious that changing of wet caves into dry must have led to microclimate changes inside caves. This has already been observed by Manchi \& Sankaran (2009) and Manchi (unpublished) that sudden changes in microclimatic conditions inside the caves of Andaman islands 
might have resulted to mortality/shifting of the several sensitive fauna from the effected caves.

As per Manchi \& Sankaran (2009) the rock fall inside the caves at Chalis-ek led to extinct the Edible-nest swiftlet (Aerodramus fuciphagus) populations from the same venue either because of disturbance in microhabitat or closure of caves entry due to blockage by rock fall. The effects on such a trogloxene species like swiftlet directly indicate that the rock falls in such tsunami affected caves must have affected/abolished various sensitive cave fauna (troglobites and stygobites) too. As baseline information regarding cave fauna in the region is lacking, in the present state it's diff icult to estimate the level of damage in this regard. Closure of five earlier known caves and vis a vis discovery of 10 new caves (Table 1) makes total number of caves in the Andaman islands from 325 to 330 and in total Andaman and Nicobar islands from 384 to 389 caves.

As the caves are most fragile structure in the world, a little disturbance in its ambient environment may harm several times more to it. As the island arc is, one of the most active parts of the earth, undergoing lot of geological changes it's important to understand composition of flora and fauna available there. Further, presence of good number of limestone caves depicts requirement of biospeleological studies in the region.

Acknowledgements:

WWF-India is highly acknowledged for the financial support. I am grateful to Saw Alexander, Saw Loren, Dhiren Das for their unreserved cooperation during the survey. Thanks are also due for the Andaman Forest Department for providing permissions to conduct survey. I would like to acknowledge Miss. Akshaya Mane who helped me at different levels during the field work

\section{References:}

Biswas J. (2009): The biodiversity of Krem Mawkhyrdop of Meghalaya, India, on the verge of extinction. Curr. Sci., 96(7); 904-910

Biswas J. (2010): Kotumsar Cave biodiversity: A review of cavernicoles and their troglobitic traits. Biodiver. Conserv., 19; 275-289.

Biswas J. \& Harries D.B. (2011): Krem Bylliat: The Harbour of Precedent Cavernicolous Representatives from the Jaintia Hills, Meghalaya, India. JBiol.Sci., 11 (7);459-465

Jafri S.H., Balaram V. \& Govil P. K., 1993, Depositional environments of Cretaceous radiolarian cherts from Andaman-Nicobar Islands, northeastern Indian Ocean. Marine Geol., 112; 291-301.

Jain S.K., Murty C.V.R., Rai D.C., Malik J.N., Sheth A. \& Jaiswal A. (2005): Effects of M 9 Sumatra earthquake and tsunami of 26 December 2004. Curr. Sci., 88(3);357-359.

Kumar S. (1990): Gravity Anomalies, Seismicity, Subducting Slab Folding and Surface Deformations in the Orogenic Belts-An Example from the Andaman-Nicobar Region. J. Geodynam., 12;39-63.

Manchi S. \& Sankaran R. (2009): Impact of the 2004 earthquake on the limestone caves in North and Middle Andaman Islands. Curr. Sci., 97 (8); 1230-1234.

Rajendran C.P., Rajendran K., Anu R., Earnest A., Machado T., Mohan P.M. \& Freymueller J. (2007): Crustal deformation and seismic history associated with the 2004 Indian Ocean earthquake: a perspective from the AndamanNicobar Islands. Bull. Seism. Soc. Am., 97; S174-S191.

Rao N.P. \& Chary A.H. (2005): What caused the great Sumatran earthquakes of 26 December 2004 and 28 March 2005? Curr. Sci., 89; 449451.

Sankaran R. (2001) The status and conservation of the Edible-nest Swiftlet (Collocalia fuciphaga) in the Andaman and Nicobar Islands. Biologic. Conserv., 97; 283-294.

Sankaran R. (1998): The impact of nest collection on the Edible-nest Swiftlet (Collocalia fuciphaga) in the Andaman and Nicobar Islands. Sálim Ali Centre for Ornithology and Natural History, Report to IUCN. Pp. 41.

Sankaran R., Andrews H. \& Vaughan A. (2005): The ground beneath the waves: post-tsunami impact assessment of wildlife and their habitats in India. Vol-2. Wildlife Trust of India, New Delhi, India. 105 p. 